\title{
14. BOLBOFORMA BIOSTRATIGRAPHY FROM THE SOUTHEAST GREENLAND MARGIN, HOLE 918D ${ }^{1}$
}

\author{
Silvia Spezzaferri ${ }^{2}$ and Dorothee Spiegler ${ }^{3}$
}

\begin{abstract}
Bolboforma is a problematic marine protophytic algae present in temperate and cool regions in both northern and southern hemispheres. It is the best calcareous microfossil group for biostratigraphic correlation of middle-upper Miocene sequence at high latitudes.

Bolboforma was found in Hole 918D during Leg 152 in the Irminger Basin (Southeast Greenland Margin). The recovered sedimentary sequence spans the interval from the middle Eocene to the Holocene. Seventeen species were identified in the interval spanning the upper Oligocene-upper Miocene. Eight zones were recognized and correlated to planktonic foraminiferal biozones and the calcareous nannoplankton zonation. The middle and upper Miocene Bolboforma zones were correlated to those identified in North Atlantic Deep Sea Drilling Project and Ocean Drilling Program Holes 116, 408, 555, 642B, 643A, and 646B. Bolboforma groenlandica $\mathrm{n}$. sp. is introduced.
\end{abstract}

\section{INTRODUCTION}

The genus Bolboforma includes calcareous microfossils of uncertain origin with affinities to protophytic algae.

They are important index fossils, which supplement, mainly at high latitudes, the standard microfossil zones based on calcareous nannofossils and planktonic foraminifers. Species belonging to this group range from the upper middle Eocene to the lower Pliocene and characterize predominantly temperate and cool regions in both northern and southern hemispheres.

Bolboforma specimens posses a generally monocrystalline, calcitic hollow and a spheroidal or subspheroidal single chamber. They display a simple aperture generally bordered by a short neck or collar. Wall texture ranges from smooth to strongly ornamented with spines, reticulations, ridges or flanges. Usually Bolboforma specimens are single-chambered, although several species may encapsulate a smaller chamber producing an encystment. The cysts are smooth or more weakly ornamented than the outer test, their classification is generally difficult and the relationships between encysted and nonencysted morphotypes are still unknown (Spiegler, 1987; Spiegler and von Daniels, 1991).

During Ocean Drilling Program (ODP) Leg 152, six sites (914919) were drilled in the Irminger Basin (Southeast Greenland Margin). Bolboforma was recovered only in Hole 918D (Fig.1). Hole $918 \mathrm{D}$ is located on the upper continental rise of the Southeast Greenland Margin, approximately $130 \mathrm{~km}$ from the Greenland coast $\left(63^{\circ} 5.572 \mathrm{~N}, 38^{\circ} 38.334 \mathrm{~W}\right)$ and was drilled at a water depth of $1868.2 \mathrm{~m}$. The hole was washed down through the first $253 \mathrm{~m}$ and then drilled with the Rotary Core Barrel (RCB) down to 1310.1 meters below seafloor (mbsf). The basement was reached at about $1206 \mathrm{mbsf}$. The cores span the interval from the middle Eocene to the Holocene.

${ }^{1}$ Saunders, A.D., Larsen, H.C., and Wise, S.W., Jr. (Eds.), 1998. Proc. ODP, Sci. Results, 152: College Station, TX (Ocean Drilling Program).

${ }^{2}$ Dipartemento di Scienze delle Terra, Università di Milano, Via Mangiagalli 34, 20133 Milano, Italy. (Present address: ETH-Zentrum, Geologisches Institut, Sonneggstrasse 5, 8092,Zurich, Switzerland.) silvia@erdw.ethz.ch

${ }^{3}$ GEOMAR, Research Center for Marine Geoscience, Wischhofstrasse 1-3, Building 4, 24148 Kiel, Federal Republic of Germany.

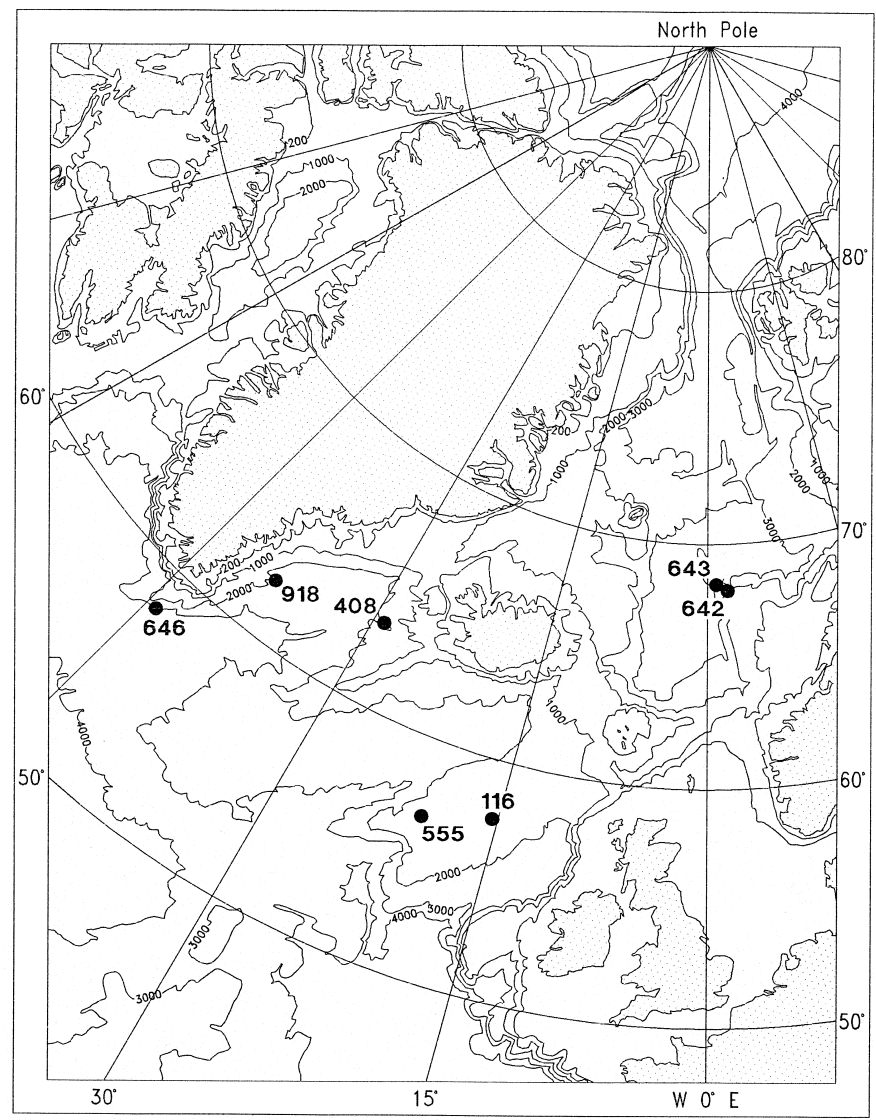

Figure 1. Location map of DSDP/ODP Holes 116, 408, 555, 642B, 643A, 646B, and 918D.

\section{MATERIALS AND METHODS}

Foraminiferal samples were also used for Bolboforma studies. Core catchers and 1-3 samples of $10 \mathrm{~cm}^{3}$ per section of each core were analyzed. 
One hundred and eighty-one samples, from $505.38 \mathrm{mbsf}$ down to 1188.16 mbsf were studied for Bolboforma (from Sample 151-918D24R-2, 68-70 cm to Sample 151-918D-96R-3, 94-96 cm). Soft sediments were washed under running water through a $40 \mu \mathrm{m}$ mesh sieve. Indurated sediments were soaked in distilled water and then washed. Samples were dried at room temperature in case some specimens proved to be suitable for isotope analyses. Bolboforma species were found in 65 samples, $36 \%$ of the total studied. Specimens of Bolboforma were picked from 40-150 $\mu \mathrm{m}$ and 150-250 $\mu \mathrm{m}$ size fractions. Bolboforma were picked in the $>250 \mu \mathrm{m}$ size fraction in only a few samples of middle Miocene sediments. The abundance of Bolboforma shown in the range chart (Table 1) is based on quantitative estimates. The preservation of Bolboforma is moderate throughout the sequence.

\section{BIOSTRATIGRAPHY}

\section{Planktonic Foraminifer Biostratigraphy}

Planktonic foraminifer biostratigraphy is reported in Spezzaferri (this volume). The zonations of Blow (1979) and Spiegler and Jansen (1989) are applied to upper Oligocene to upper Miocene sediments. Miocene sediments are present in Hole 918D, but the biostratigraphic resolution of planktonic foraminifers is low at high latitudes.

Of the upper Miocene zones, only Neogloboquadrina atlantica dextral and Neogloboquadrina acostaensis are present (Samples 152918D-24R-3, 26-28 cm, through 37R-3, 13-16 cm). Planktonic foraminiferal data indicate that the upper middle Miocene Zone N15 is probably missing. The middle Miocene interval spanning Zones N9N14 is present, but zonal boundaries are not identified (Samples 152918D-37R-3, 58-60 cm, through 44R-3, 98-101 cm). The lower Miocene Zones N4b-N8 are identified from Samples 152-918D-44R-4, 97-100 cm, through 58R-1, 42-44 cm). Upper Oligocene Zones P22 and P21 are identified from Samples 152-918D-62R-1, 87-89 cm, through 63R-1, 93-96 cm, and from Samples 152-918D-63R-2, 34$36 \mathrm{~cm}$, through $86 \mathrm{R}-2,69-71 \mathrm{~cm}$, respectively.

\section{Calcareous Nannoplankton Biostratigraphy}

Calcareous nannoplankton biostratigraphy is reported in Wei (this volume). The zonation of Okada and Bukry (1980) is applied to Hole 918D sediments. Several zonal boundaries, however, are not clearly identified.

Section 152-918D-24R-2 is attributed to the lower Pliocene Zone CN10; the interval Zones CN9-CN7 is identified from Samples 152918D-24R-3, $49 \mathrm{~cm}$, through 37R-3, $88 \mathrm{~cm}$. Samples 152-918D$37 \mathrm{R}-3,25 \mathrm{~cm}$, through 42R-6, $68 \mathrm{~cm}$, contain calcareous nannofossil assemblages attributable to the interval spanning Zones CN6-CN5. The interval Zones CN4-CN3 is identified from Samples 152-918D42R-CC through 53R-3, $77 \mathrm{~cm}$. The lower Miocene Zones CN2 and CN1 are identified from Samples 152-918D-53R-4, $77 \mathrm{~cm}$, through 57R-3, 34 cm. Samples 152-918D-58R-CC through 86R-2, $64 \mathrm{~cm}$, yield floral assemblages attributed to the upper Oligocene undifferentiated interval spanning Zones CP19-CP17.

\section{Bolboforma Biostratigraphy}

Preliminary biostratigraphic data on Bolboforma assemblages identified in Hole 918D are included in Larsen, Saunders, Clift, et al. (1994). The main characteristics of Bolboforma assemblages, their stratigraphic distribution, and the intensity of dissolution are reported here in more detail. The major events used for identifying the zonal boundaries and zones are the same used in Spiegler and von Daniels (1991), Spiegler and Müller (1992), and Grützmacher (1993). They are reported from oldest to youngest.
1. The co-occurrence of Bolboforma spinosa and Bolboforma sp. 2, aff. B. antarctica marks the B. spinosa Zone in the upper Oligocene.

2. Occurrence of Bolboforma irregularis in the upper Oligocene.

3. FO (first occurrence) and LO (last occurrence) of Bolboforma sp. 1, aff. B. spinosa in the lower Miocene.

4. FO of Bolboforma reticulata equated to the base of B. reticulata Zone, middle Miocene.

5. The occurrence of Bolboforma danielsi marks the B. danielsi Zone, middle Miocene.

6. The occurrence of the oblate Bolboforma compressibadenensis indicates the presence of the lower part of the Bolboforma compressispinosa Zone, upper middle Miocene.

7. The FO and the LO of Bolboforma subfragoris and Bolboforma fragori mark the uppermost middle Miocene sequence.

8. The FO of B. laevis marks the base of the upper Miocene.

9. The FO of Bolboforma metzmacheri is equated to the B. metzmacheri Zone, upper Miocene.

10. Occurrence of Bolboforma groenlandica $\mathrm{n}$. sp.(see taxonomic notes), in the B. metzmacheri Zone, upper Miocene.

\section{RESULTS}

The distribution of the identified species of Bolboforma, the identified biozones together with cysts of different Bolboforma taxa, and the occurrence of reworking are reported in Table 1 . They are also reported in the Hole 918D log with biostratigraphic correlation of planktonic foraminifers and calcareous nannoplankton (Fig. 2).

The upper Miocene assemblages are moderately preserved and show signs of smoothing of ornamentations by abrasion. Nine samples of the 27 analyzed contain Bolboforma. Assemblages consist of only four species: B. laevis, B. metzmacheri, B. groenlandica, and Bolboforma sp. B, Pallant and Kaminski. Bolboforma metzmacheri and B. laevis Zones are identified from 505.38 to $600.81 \mathrm{mbsf}$ and from 620.20 to $621.63 \mathrm{mbsf}$, respectively.

The stratigraphic resolution of Bolboforma is higher in the middle Miocene. The assemblages are richer and the specimens are better preserved than they are in the upper Miocene. Bolboforma has been found in 40 of the 65 analyzed samples within this interval. Eight species were identified: $B$. spinosa, $B$. danielsi, $B$. reticulata, $B$. compressibadenensis, B. capsula, B. badenensis, B. fragori, and B. subfragoris. Bolboforma subfragoris Zone is identified from 631.73 to $632.18 \mathrm{mbsf}$; $B$. compressispinosa Zone is identified only in Sample 152-918D-37R-3, 58-60 cm (depth = 632.18 mbsf); B. badenensis Zone is identified from 634.28 to $639.18 \mathrm{mbsf}$; . danielsi Zone is present only in Sample 152-918D-38R-2, 114-116 cm $($ depth = $648.84 \mathrm{mbsf}$ ); and $B$. reticulata Zone is present from 641.80 to 726.15 mbsf.

The lower part of the middle Miocene and the lower Miocene are generally barren of Bolboforma. The lowermost Miocene assemblages are poorly preserved and Bolboforma is rare. Seven samples of the 44 analyzed contain Bolboforma. Only B. spiralis and very smallsized specimens of Bolboforma sp. 1, aff. spinosa were identified.

Oligocene assemblages are very poor and consist mainly of small specimens of Bolboforma. Only five of the 46 samples attributed to the upper Oligocene contain Bolboforma. Four species were identified: B. spinosa; B. sp. 2, aff. B. antarctica; B. irregularis; and B. rotunda.

\section{DISCUSSION}

Qvale and Spiegler (1989) and Spiegler and von Daniels (1991) defined Bolboforma zones, whereas Spiegler and Müller (1992) cor- 
Table 1. Stratigraphic distribution of Bolboforma in samples from Hole 918D plotted together with number of barren samples and reworked specimens.

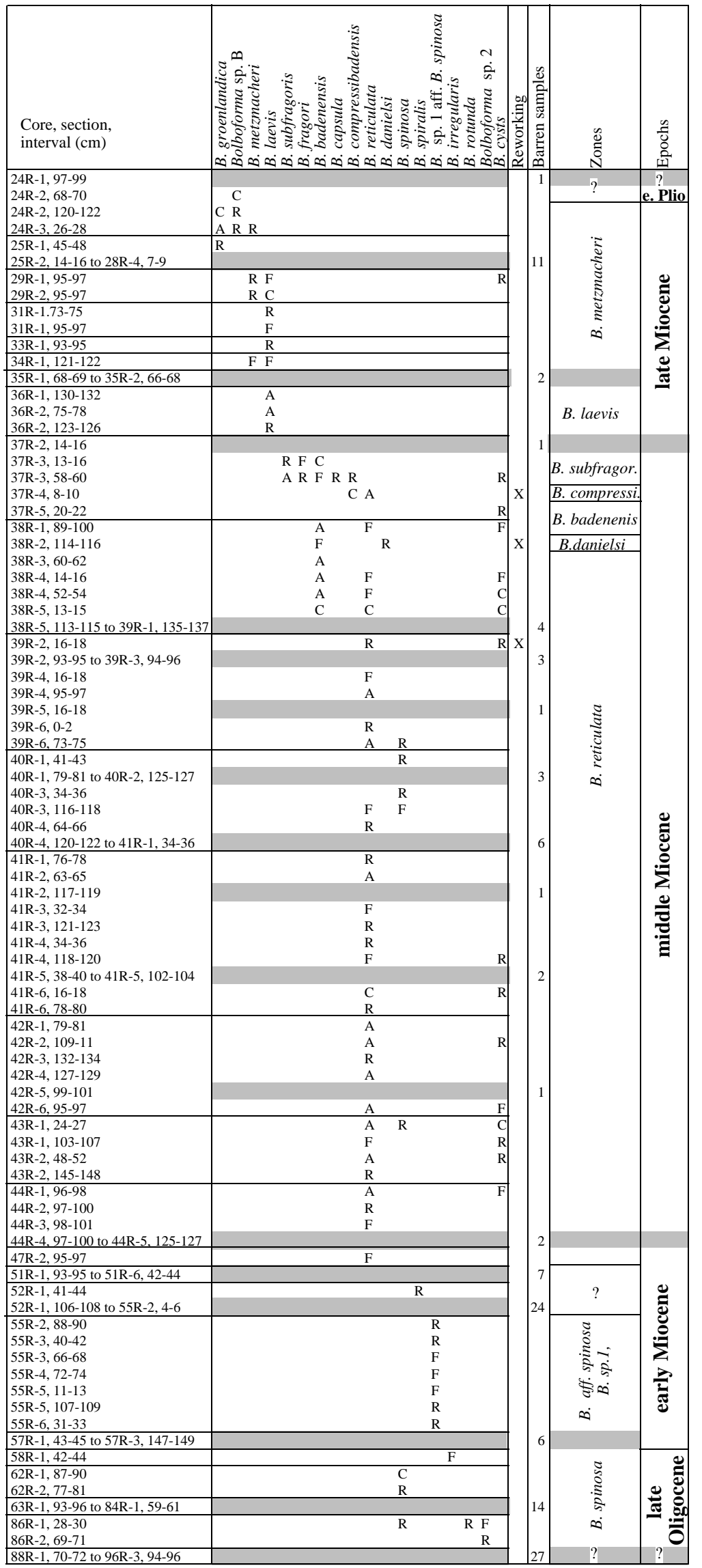

Notes: Rare $(R)=<3$ specimens, few $(F)=3-15$ specimens, common $(C)=16-50$ specimens, and abundant $(A)=>50$ specimens. 


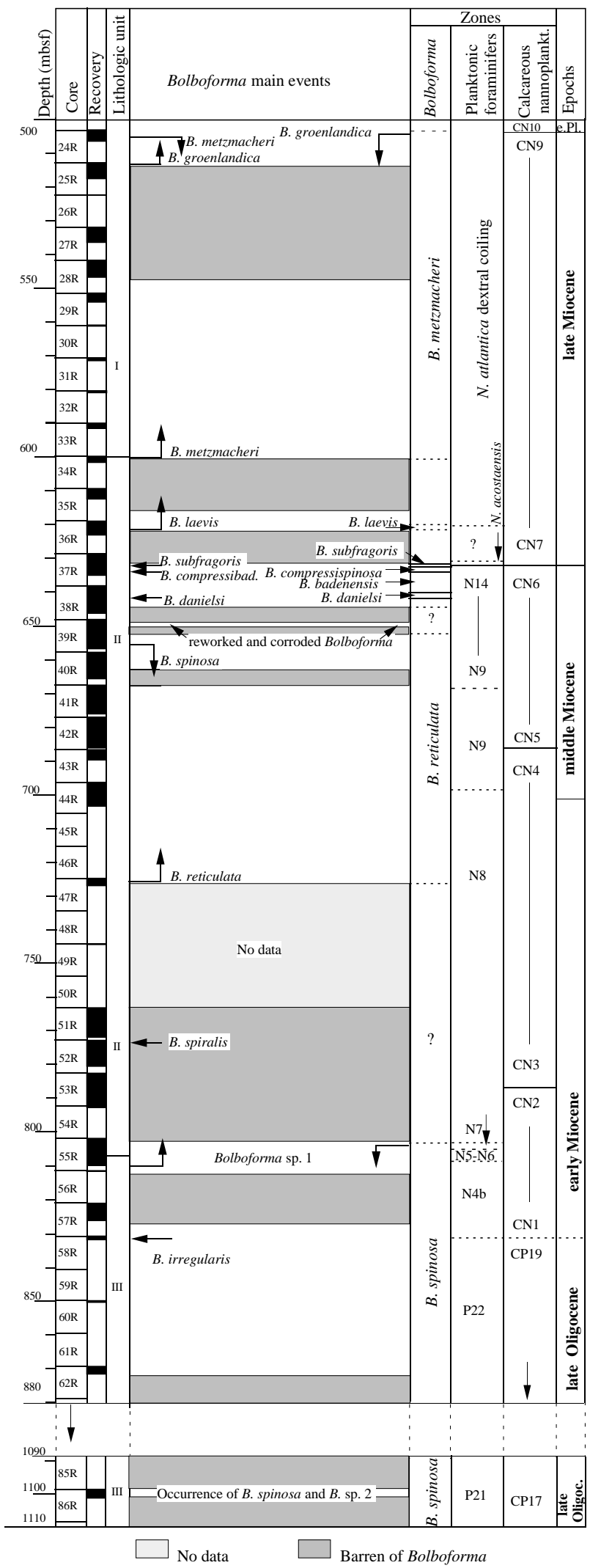

Figure 2. Depth, cores, recovery, and lithologic units plotted vs. Bolboforma and planktonic foraminifers and calcareous nannofossil zones identified in Hole 918D. related the Neogene Bolboforma zones to nannoplankton zones. Eight of those zones are identified in Hole 918D. However, barren samples in some cases prevent clear identification of Bolboforma zonal boundaries. Therefore, some of the zones, especially in the upper part of the middle Miocene sequence, seem to be condensed.

Bolboforma metzmacheri Zone is identified from Sample 152918D-24R-2, 68-70 cm to Sample 152-918D-34R-1, 121-122 cm. This species is present together with $B$. groenlandica $n$. sp. The latter form was first observed by Pallant and Kaminski (1989) in upper Miocene sediments of the Labrador Sea at Site 646 and referred to as Bolboforma sp. A. The other species in open nomenclature, Bolboforma sp. B Pallant and Kaminski, also occurs in rare abundance and poor preservation in Sections 152-918D-24X-2 through 24X-3. Both occur in the Labrador Sea along with B. metzmacheri in upper Miocene sediments.

The upper/middle Miocene boundary lies between B. laevis and B. subfragoris Zones (Spiegler and Müller, 1992). These zones are separated in Hole 918D by an interval barren of Bolboforma. Therefore, it is tentatively placed at the top of the B. subfragoris Zone. The latter zone is only $0.45 \mathrm{~m}$ thick in Hole 918D. It is from 6 to $30 \mathrm{~m}$ thick in the North Atlantic, which corresponds to an interval of about 1.5 m.y. (Spiegler and Müller, 1992); therefore, some portions may be missing in Hole 918D. The presence of the flat B. compressibadenensis, in the absence of the most evolved specimen $B$. compressispinosa, indicates that the upper part of the B. compressispinosa Zone is probably also missing.

Reworking is documented by the abundant occurrence of corroded $B$. reticulata in the $B$. compressispinosa and B. badenensis Zones (Sample 152-918D-37R-4, 8-10 cm, and 38R-1, 98-100 cm, respectively) and by the occurrence of corroded Bolboforma spp. in Sample 152-918D-39R-2, 16-18 cm.

Bolboforma danielsi occurs in Sample 152-918D-38R-2, 114$116 \mathrm{~cm}$. It is a distinct and excellent marker species in the upper part of the middle Miocene (about $12 \mathrm{Ma}$ ) in the North Atlantic and the Northwest European shelf area (Spiegler and Müller, 1992).

The presence of $B$. spinosa together with rare, poorly preserved specimens of $B$. irregularis suggests a possible late Oligocene age (Sample 152-918D-58R-1, 42-44 cm). Bolboforma irregularis was previously found only in the Hamburg region (Northwest Germany) in the upper Oligocene.

\section{CORRELATION WITH DSDP/ODP HOLES IN THE NORTH ATLANTIC}

The correlation of Hole 918D with the Neogene Bolboforma zones identified in the North Atlantic Deep Sea Drilling Project (DSDP) and ODP Holes 408, 116, 555, 643A, and 642B is shown in Figure 3 . All of the holes are equated to the base of B. laevis Zone, which marks the upper/middle Miocene boundary.

The upper Miocene B. metzmacheri and B. laevis Zones are present in all of these holes; however, they are reduced in thickness in some of them. The B. metzmacheri Zone is also present in Hole $646 \mathrm{~B}$ in the Labrador Sea, but the marker species together with $B$. groenlandica was found in two samples only. Bolboforma subfragoris and $B$. compressispinosa were missing only in Hole 116 due to lack of continuous coring. The $B$. badenensis Zone is present in all of the regions.

The distinct and short-range species $B$. danielsi marks the $B$. danielsi Zone, which is missing only in the Vøring Plateau Holes 642B and 643A (Müller and Spiegler, 1993). The B. reticulata Zone is always present in the North Atlantic.

\section{CONCLUSIONS}

Three main conclusions can be drawn: (1) Seventeen Bolboforma species and eight Bolboforma zones are identified in Hole 918D (East 
Hole 918D

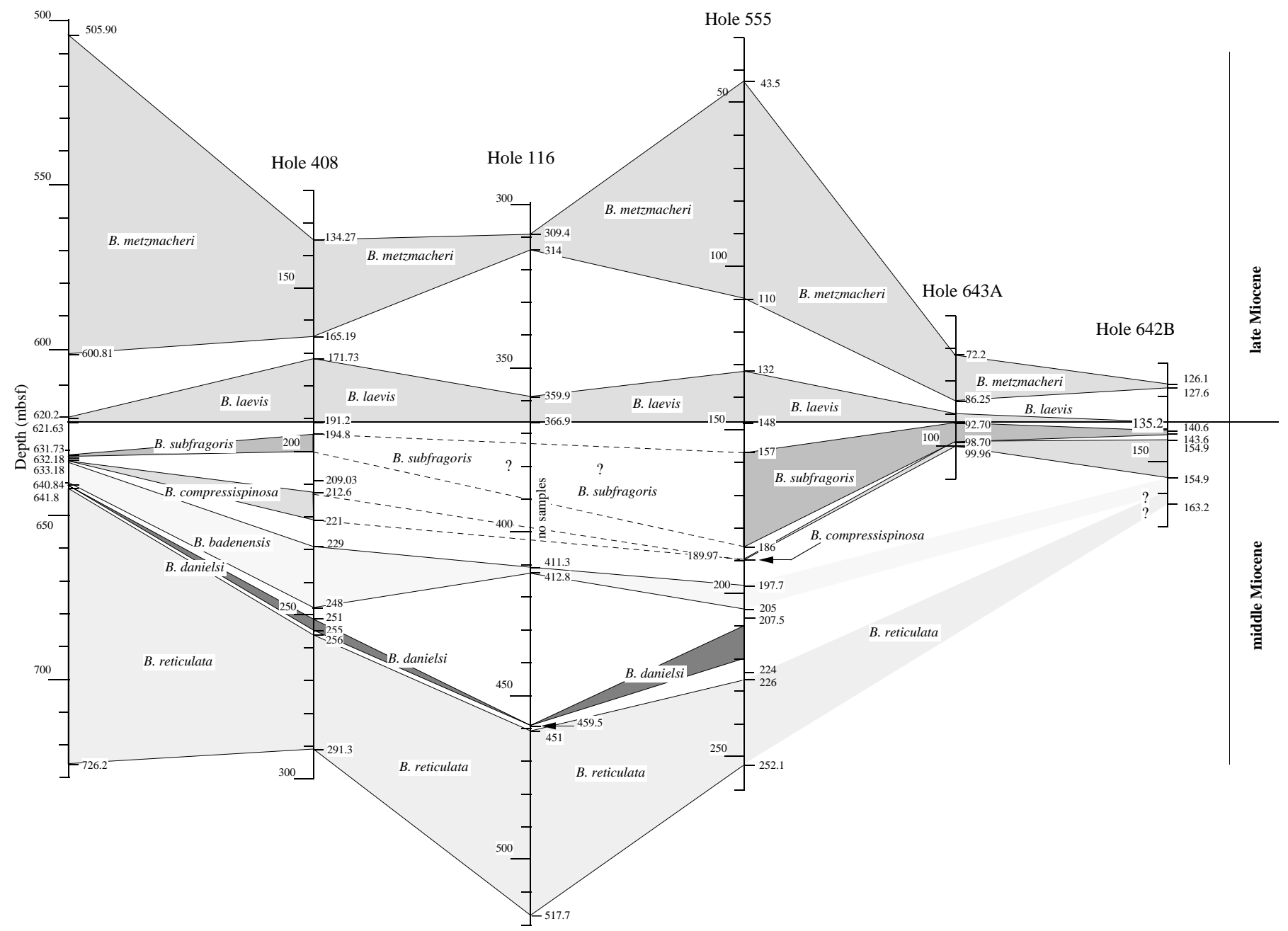

Figure 3. Correlation of the Bolboforma zones identified in Hole 918D with those identified and described in North Atlantic Holes 408, 555, 116, 642B, and $643 \mathrm{~A}$. The white pattern marks those intervals with no data, barren samples, or no recovery.

Greenland Margin); (2) Bolboforma is present throughout the North Atlantic and is the best calcareous microfossil group for biostratigraphic correlation of middle-upper Miocene sequences at these high latitudes; and (3) the new species $B$. groenlandica is introduced and described from the upper Miocene sediments.

\section{TAXONOMIC NOTES}

Bolboforma groenlandica Spezzaferri and Spiegler n. sp. (Pl. 1, Figs. 1-2, 4)

Bolboforma sp. A, Pallant and Kaminski, 1989, p. 385 (pl. 1, fig 2)

Diagnosis: Test aborally flattened and ornamented by irregular horizontal ridges.

Description: Test unicamerate, subspheroidal, aborally flattened, orally distinct neck with circular aperture. Ornamented by five to seven subcontinuous horizontal ridges. Small perpendicular ridges connect the radial ridges. Around the aperture the ridges are more irregular. Cyst (Pl. 1, Fig. 4) smaller in size and more weakly ornamented.

Remarks: B. subfragoris and B. fragori are larger in size and more coarsely ornamented.

Occurrences: Irminger Basin, ODP Cores 152-918D-24R and 25R. Labrador Sea, ODP Sample 105-646B-74X-4, 10-12 cm.

Size: Test diameter 100-150 $\mu \mathrm{m}$; holotype $120 \mu \mathrm{m}$.

Holotype: Pl. 1, Fig. 1.

Isotype: Pl. 1, Fig. 2.
Type specimens are housed in Natural History Museum Basel, Switzerland.

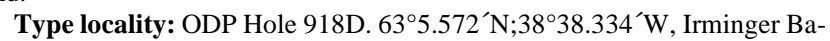
$\sin$.

Type horizon: Sequence from Samples 152-918D-24R-2, 120-122 cm, to 25R-1, 45-48 cm (505.90-513.25 mbsf), upper Miocene.

Stratigraphic range: Upper Miocene, Neogloboquadrina atlantica dextral coiling Zone (planktonic foraminifers), Zone NN11 (calcareous nannoplankton), Bolboforma metzmacheri Zone.

Etymology: From Greenland.

\section{Bolboforma sp. B, Pallant and Kaminski}

$$
\text { (P1. 1, Fig. 3) }
$$

Bolboforma sp. B, Pallant and Kaminski, 1989, p. 385 (pl. 1, fig. 3)

Description: Test unicamerate, subspheroidal, aborally flattened. The irregular ridges are covered by blunt (corroded?) spines.

Remarks: The badly preserved specimens prevent a better identification.

Occurrence: Rare in Samples 152-918D-24R-2, 120-122 cm, and 24R$3,26-28 \mathrm{~cm}$.

Bolboforma sp 1, aff. B. spinosa Daniels and Spiegler, 1974 (pl. 2, figs. 5-6)

Description: The spheroid tests, only $100 \mu \mathrm{m}$ in size, are irregularly covered by blunt knobs.

Remarks: The test of $B$. spinosa is more elongate and mostly larger. The spines are coarser. 
Occurrence: Sections 152-918D-55R-2 through 6, lower Miocene.

Bolboforma sp. 2, aff. B. antarctica Kennett and Kennett, 1990 (pl. 2, fig. 11)

Description: The spheroid test is ornamented by five to six reticulations in equatorial view.

Remarks: The reticulation is generally more coarsely developed than in typical $B$. antarctica of the middle Eocene and resembles the upper Eocene forms from the Labrador Sea (Spiegler and von Daniels, 1991, pl. 5, fig. 6). The knowledge of Oligocene Bolboforma is limited.

Occurrence: Sections 152-918D-86R-1 through 2, upper Oligocene.

\section{FAUNAL REFERENCE LIST}

Type references are given for each species recognized.

Bolboforma antarctica Kennett and Kennett, 1990, p. 673, pl. 1, figs. 1-7. Bolboforma capsula Spiegler, 1987, p. 162, pl. 2, figs. 4-6.

Bolboforma badenensis Szczechura, 1982, p. 33, pl. 6, figs. 1-4.

Bolboforma compressibadenensis Spiegler. See Spiegler and von Daniels, 1991, p. 134, pl. 2, figs. 5-6.

Bolboforma danielsi Murray, 1984, p. 538, pl. 1, figs. 13-15, 18-20.

Bolboforma fragori Powell, 1986, p. 71, pl. 1, figs. 1-4.

Bolboforma irregularis Daniels and Spiegler, 1974, p. 69, pl. 10, figs. 4-5.

Bolboforma laevis Daniels and Spiegler, 1974, p. 64, pl. 7, figs. 7-9; pl. 10, fig. 6.

Bolboforma metzmacheri (Clodius), 1922, p. 108, pl. 1, fig. 2.

Bolboforma reticulata Daniels and Spiegler, 1974, p. 64, pl. 7, figs. 10-11.

Bolboforma rotunda Daniels and Spiegler, 1974, p. 67, pl. 8, fig. 10; pl. 9, figs. 1-2.

Bolboforma spinosa Daniels and Spiegler, 1974, p. 67, pl. 9, figs. 3-4.

Bolboforma spiralis Daniels and Spiegler, 1974, p. 68, pl. 9, figs. 5-8.

Bolboforma subfragoris Spiegler. See Spiegler and von Daniels, 1991, p. 140, pl. 11, figs. 3-6.

\section{ACKNOWLEDGMENTS}

Thanks to ODP for inviting SS on board for Leg 152. Thanks to Agostino Rizzi and to Centro di Studio per la Geodinamica Alpina e Quaternaria (CNR) for operation at the electronic microscope. Giovanni Chiodi printed the photographs. Thanks also to Colin Bremner for his help during the first draft of this paper. Thanks to F. Rögl, D.M. Kennett, and J.P. Kennett for their revisions and comments, which greatly improved this manuscript. Financial support was given to DS by the Deutsche Forschungs-gemeinschaft Bonn and to SS from Università degli Studi di Milano and Consiglio Nazionale delle Ricerche (CNR).

\section{REFERENCES}

Blow, W.H., 1979. The Cainozoic Globigerinida: Leiden (E.J. Brill).

Clodius, G., 1922. Die Foraminiferen des obermiozänen Glimmertons in Norddeutschland mit besonderer Berücksichtigung der Aufschlüsse in Mecklenburg. Arch. Freunde Natur. Mecklenburg, 75:76-145.
Daniels, C.H. von, and Spiegler, D., 1974. Bolboforma n. gen. (Protozoa?) eine neue stratigraphisch wichtige Gattung aus dem Oligozän/Miozän Nordwestdeutschlands. Palaontol. Z., 48:57-76.

Grützmacher, U., 1993. Die Veränderungen der paläogeographischen Verbreitung von Bolboforma: Ein Beitrag zur Rekonstruktion und Definition von Wassermassen im Tertiär. Geomar Rep., 22:1-104.

Kennett, D.M., and Kennett, J.P., 1990. Bolboforma Daniels and Spiegler, from Eocene and lower Oligocene sediments, Maud Rise, Antarctica. In Barker, P.F., Kennett, J.P., et al., Proc. ODP, Sci. Results, 113: College Station, TX (Ocean Drilling Program), 667-673.

Larsen, H.C., Saunders, A.D., Clift, P.D., et al., 1994. Proc. ODP, Init. Repts., 152: College Station, TX (Ocean Drilling Program).

Müller, C., and Spiegler, D., 1993. Revision of late/middle Miocene boundary on the Vøring Plateau (ODP Leg 104). Newsl. Stratigr., 28:171-178.

Murray, J.W., 1984. Biostratigraphic value of Bolboforma, Leg 81, Rockall Plateau. In Roberts, D.G., Schnitker, D., et al., Init. Repts. DSDP, 81: Washington (U.S. Govt. Printing Office), 535-539.

Okada, H., and Bukry, D., 1980. Supplementary modification and introduction of code numbers to the low-latitude coccolith biostratigraphic zonation (Bukry, 1973; 1975). Mar. Micropaleontol., 5:321-325.

Pallant, A., and Kaminski, M., 1989. Bolboforma from Leg 105, Labrador Sea and Baffin Bay, and the chronostratigraphy of Bolboforma in the North Atlantic. In Srivastava, S.P., Arthur, M.A., Clement, B., et al., Proc. ODP, Sci. Results, 105: College Station, TX (Ocean Drilling Program), 381-385.

Powell, A., 1986. A new species of Bolboforma (inc.sed.) from the Miocene of the Vøring Plateau, Northern Norway. J. Micropaleontol., 5:71-74.

Qvale, G., and Spiegler, D., 1989. The stratigraphic significance of Bolboforma (algae, Chrysophyta) in Leg 104 samples from the Vøring Plateau. In Eldholm, O., Thiede, J., Taylor, E., et al., Proc. ODP, Sci. Results, 104: College Station, TX (Ocean Drilling Program), 487-495.

Spiegler, D., 1987. Encapsulated Bolboforma (Algae, Chrysophyta) from upper Miocene deposits in the North Atlantic. Meded. Werkgr. Tert. Kwart. Geol., 24:157-166.

Spiegler, D., and Jansen, E., 1989. Planktonic foraminifer biostratigraphy of Norwegian Sea sediments: ODP Leg 104. In Eldholm, O., Thiede, J., Taylor, E., et al., Proc. ODP, Sci. Results, 104: College Station, TX (Ocean Drilling Program), 681-696.

Spiegler, D., and Müller, C., 1992. Correlation of Bolboforma zonation and nannoplankton stratigraphy in the Neogene of the North Atlantic: DSDP Sites 12-116, 49-408, 81-555 and 94-608. Mar. Micropaleontol., 20:4558.

Spiegler, D., and von Daniels, C.H., 1991. A stratigraphic and taxonomic atlas of Bolboforma (Protophytes, Incertae sedis, Tertiary). J. Foraminiferal Res., 21:126-158.

Szczechura, J., 1982. Middle Miocene foraminiferal biochronology and ecology of SE Poland. Acta Paleontol. Polon., 27:2-44.

Date of initial receipt: 2 October 1995

Date of acceptance: 24 May 1996

Ms 152SR-213 


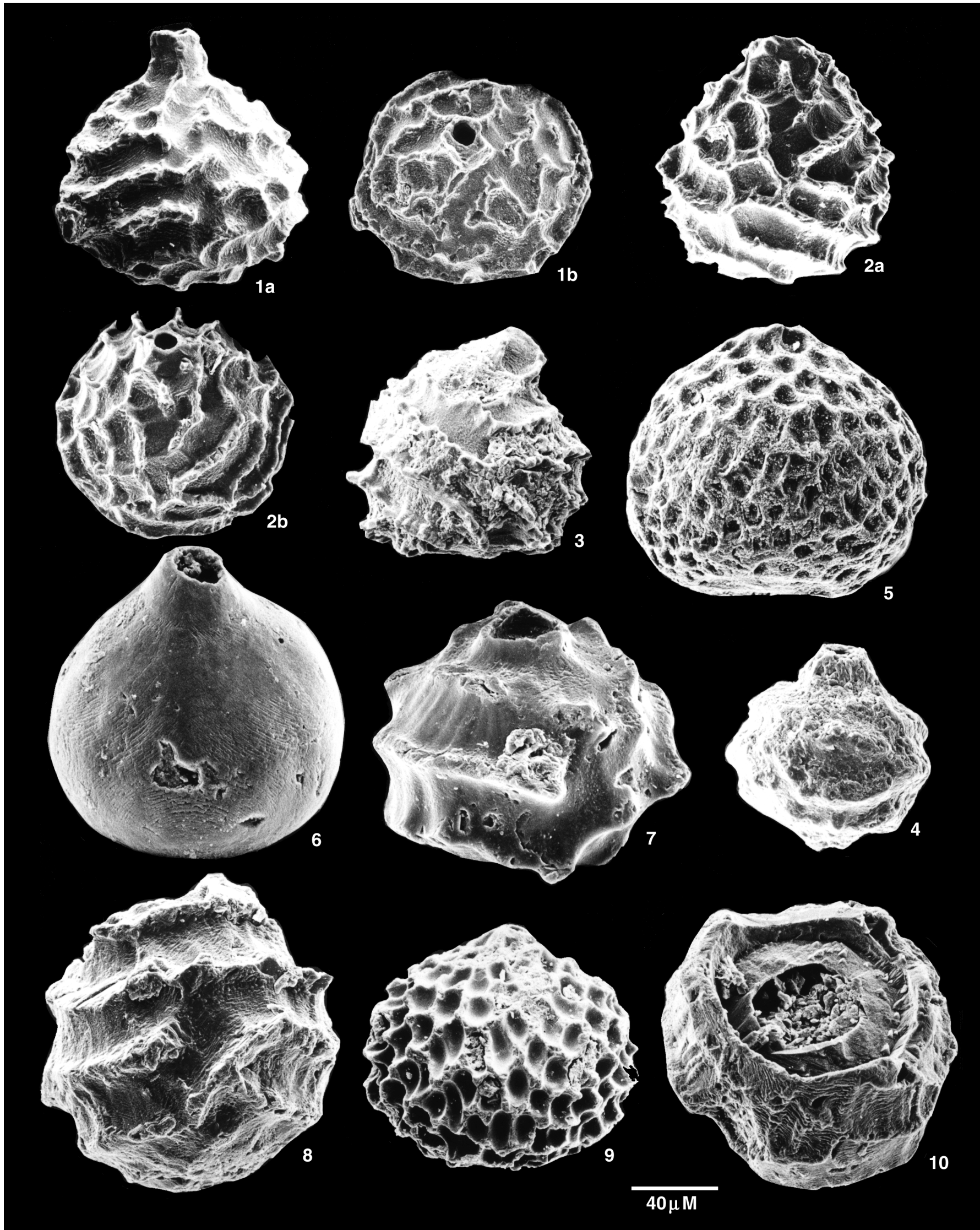

Plate 1. Bolboforma from East Greenland Margin. 1-2. Bolboforma groenlandica n. sp. 1. Holotype, Sample 152-918D-24R-2, 120-122 cm. 2. Sample 152918D-24R-3, 26-28 cm. 3. Bolboforma sp. B, Pallant and Kaminski, Sample 152-918D-24R-3, 26-28 cm. 4. Cyst, probably from Bolboforma groenlandica, Sample 152-918D-24R-2, 68-70 cm. 5. Bolboforma metzmacheri (Clodius), Sample 152-918D-29R-1, 95-97 cm. 6. Bolboforma laevis Daniels and Spiegler, Sample 152-918D-32R-1, 95-97 cm. 7. Bolboforma fragori Powell, 152-918D-37R-3, 13-16 cm. 8. Bolboforma subfragoris Spiegler, Sample 152-918D-37R3, 56-60 cm. 9. Bolboforma badenensis Szczechura, Sample 152-918D-37R-3, 16-18 cm. 10. Bolboforma capsula Spiegler, Sample 152-918D-37R-3, 16-18 $\mathrm{cm}$. 

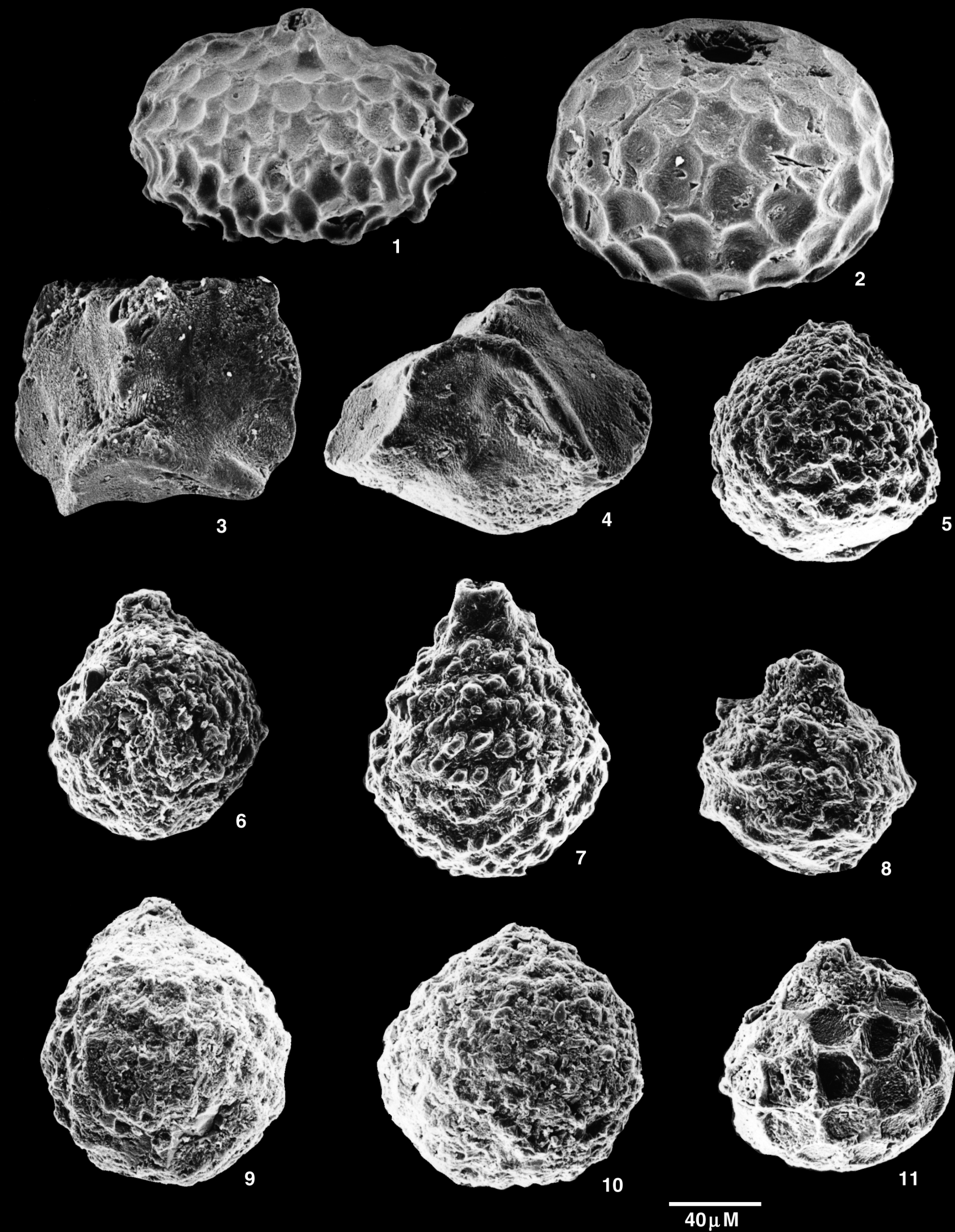

Plate 2. Bolboforma from East Greenland Margin. 1. Bolboforma compressibadenensis Spiegler, Sample 152-918D-37R-4, 8-10 cm. 2. Bolboforma reticulata Daniels and Spiegler, Sample 152-918D-37R-4, 8-10 cm. 3-4. Bolboforma danielsi Murray, Sample 152-918D-38R-2, 114-116 cm. 5-6. Bolboforma sp. 1, aff. B. spinosa Daniels and Spiegler, Sample 152-918D-55R-4, 72-74 cm. 7. Bolboforma spinosa Daniels and Spiegler, Sample 152-918D-62R-1, 87-90 cm. 8. Bolboforma irregularis Daniels and Spiegler, Sample 152-918D-58R-1, 42-44 cm. 9-10. Bolboforma rotunda Daniels and Spiegler, Sample 152-918D-86R-1, $28-30 \mathrm{~cm}$. 11. Bolboforma sp.2, aff. B. antarctica Kennett and Kennett, Sample 152-918D-86R-1, 28-30 cm. 